\title{
Role of Local Non-Governmental Organizations (NGOs) in Community Development in Zamfara State, Nigeria
}

\author{
A Hashim, S.H Sidi, B.Z Abubakar, B.F Umar, H.M Aliero, F.J Yelwa
}

Department of Agricultural extension and rural development, Usmanu Danfodiyo University, Sokoto, Nigeria. Email: Corresponding author: ahmadhashim70@gmail.com

\begin{abstract}
The study was conducted in Zamfara State, Nigeria to assess the role of local Non-Governmental Organizations (NGOs) in community development. A questionnaire was administered to 200 randomly selected beneficiaries of NGOs activities. Another questionnaire was administered to 58 purposively sampled officials of local NGOs for the study. Descriptive such as (frequencies and percentages) and inferential statistics like t-test and correlation were used to analyze the data collected from the field. The study revealed that, local NGOs contributes significantly to community development in various ways such as through community self-help efforts; training and re-training of community members and awareness creation and sensitization of community members. It was revealed that, these efforts resulted to many improvements such as increased enrolments of children in schools; improved health care service delivery; and increased agricultural yields. The research has shown that, beneficiaries provide water; labour and venue during execution of community development efforts. The study identified problems militating against smooth running of NGOs activities: inadequate funds and personnel; low level of beneficiaries 'commitments; and low level of government support. It was recommended that, government, individuals and development partners should provide more financial, technical and human resources support to NGOs in order to make them effective and efficient in delivery of community development services.
\end{abstract}

Keywords - Role; Local Non-Governmental Organizations (NGOs); Community development.

\section{INTRODUCTION}

Poor performance of governments in meeting the socioeconomic quests of its citizens has been identified as one of the reasons behind the proliferation of Community Based Organizations (CBOs) and Non-Governmental Organizations (NGOs) in the present Millennium. Non-Governmental Organizations (NGOs) are voluntary clubs, societies and associations or groups of people within the society or community that come together to achieve certain objectives (United Nations 1990). They may have similar identities and share some needs and aspirations. These organizations are non-profit or business oriented. Non-Governmental Organizations (NGOs) are organizations or societies that have little or no direct bearing with any of the three levels of government; in most cases they do not have permanent paid officials (United Nations, 1990).

There is increasing evidence that all three sectors of societygovernment, private and civil society (NGOs)-have important roles to play in nations' building and particularly in development efforts to improve the quality of lives of citizens. When they are able to work well together they mutually reinforce each other's work and can together do what none of them can do on its own. These collaborative and working relationships have not been documented in the case of Zamfara State.

The study was conducted to achieve the following Objectives:

i. Describe the socio-economic characteristics of beneficiaries of community development activities;

ii. Identify the roles played by the NGOs in community development;

iii. Find out Roles of beneficiaries towards execution of community development activities in the area;

iv. Identify the perception of beneficiaries towards NGOs in community development;

v. Find out forms of assistance provided by government in supplementing the efforts of the NGOs in the study area; and 
vi. Investigate problems of NGOs as perceived by the beneficiaries in the study area;

\section{METHODOLOGY}

The research was conducted in Zamfara State, Nigeria; Gusau is the capital of the state. The area is located on latitude $12^{\circ} 10^{\prime} \mathrm{N}$ and longitude $12^{\circ} 16^{\prime} \mathrm{E}$. It was created in October 1996 by the then head of state Late General Sani Abacha; It has 14 Local government areas sparsely distributed across the state. It was created from former Sokoto state. The State is bordered in the north by Niger republic, to the south by Kaduna State, in the east it is bordered by Katsina state and the west by Sokoto, Kebbi and Niger States, (Zamfara State government Bulletin, 2012). The total area covered by the state is $39,762 \mathrm{~km} 2$ with of $3,602,356$ people (NPC, 2006).Ninety percent of populations are farmers and or offering services to the growing agricultural industries in the area (NPC, 2006). The climate of the area favors growth and development of millet, sorghum, maize, cotton, groundnuts, cowpea, tobacco and locust beans etc. and also is generally relative to its tropical position. Highest maximum and minimum annual temperatures are $38^{\circ} \mathrm{c}$ and $18^{\circ} \mathrm{c}$ respectively. A hamattan period, which falls between December to February, is characterized by very cold temperature and dust-laden winds, often accompanied by thick fog of high intensity. The main annual rainfall is $853.40 \mathrm{~mm}$, which is enough to support healthy growth of lot of tropical crops (Zamfara State Government Bulletin, 2012).The soil is generally sandy loam moderately fertile and easy to cultivate. There are two major ethnic groups; Hausa and Fulani who were predominantly farmers, rearers and businessmen, other tribes are also available which include; Yoruba, Igbo, Ibira, Tiv, Nupe, Zabarmawa and many other minority tribes. Islam is the predominant religion in the area. The vegetation characteristics are of the Sudan Savannah type with abundant grassland and sparse trees. The area is situated in the southern Sudan Savannah zone. (Zamfara State Government Bulletin, 2012).

The research work was carried out using a list of 58 registered local NGOs operating in the state. This formed the study sample frame. The list was obtained from Zamfara State Agency for NGOs affairs. In selecting the beneficiaries, purposive and simple random sampling techniques were used. Village heads and 9 other persons from each village were selected from 20 villages. A total of 200 copies of beneficiaries' questionnaire were administered. In each of 20 surveyed villages, a Focused Group Discussion was held.
Both primary and secondary data were used. Well-structured questionnaires were framed and relevant information from Non-Governmental Organizations (NGOs) and selected community members who benefited from NGOs interventions were obtained. The questionnaires were administered to officials of the NGOs and beneficiaries in the study area. A Focused Group Discussion guide was also developed and used. The data collection was done in May 2018 using the three instruments highlighted above. Other techniques used in data collection included; likert scale, triangulation and ranking.

\section{RESULTS AND DISCUSSION}

Table 1: Socio-Economic Characteristics of Beneficiaries of NGOs efforts $(n=200)$

\begin{tabular}{|c|c|c|}
\hline Parameters & Frequency & Percentage \\
\hline \multicolumn{3}{|l|}{ Sex } \\
\hline Male & 141 & 70.5 \\
\hline Female & 59 & 29.5 \\
\hline \multicolumn{3}{|l|}{ Age Group (Years) } \\
\hline $10-20$ & 40 & 20.0 \\
\hline $21-30$ & 56 & 28.0 \\
\hline $31-40$ & 77 & 38.5 \\
\hline $41-50$ & 22 & 11.0 \\
\hline $51-60$ & 5 & 2.5 \\
\hline \multicolumn{3}{|l|}{ Education status } \\
\hline Islamic education & 26 & 13.0 \\
\hline Adult education & 15 & 7.5 \\
\hline Primary education & 99 & 49.5 \\
\hline Secondary education & 39 & 19.5 \\
\hline Tertiary education & 11 & 5.5 \\
\hline \multicolumn{3}{|l|}{ Occupation } \\
\hline Civil servant & 48 & 24.0 \\
\hline Farmer & 114 & 57.0 \\
\hline Trader & 26 & 13.0 \\
\hline Other petty business & 12 & 6.0 \\
\hline \multicolumn{3}{|l|}{ Marital status } \\
\hline Married & 170 & 85.0 \\
\hline Single & 17 & 8.5 \\
\hline Divorced & 11 & 5.5 \\
\hline Widow & 2 & 1.0 \\
\hline \multicolumn{3}{|l|}{ (Persons) } \\
\hline Less than 5 & 99 & 49.5 \\
\hline $5-10$ & 86 & 43.0 \\
\hline $11-20$ & 13 & 6.5 \\
\hline 21 and above & 2 & 1.0 \\
\hline
\end{tabular}




\begin{tabular}{|c|c|c|c|}
\hline \multirow{2}{*}{\multicolumn{4}{|c|}{$\begin{array}{l}\text { Family Income } \\
\text { Level per Annum }\end{array}$}} \\
\hline & & & \\
\hline $\mathrm{N} 100,000$ & & 111 & 55.5 \\
\hline N500,000 & & & \\
\hline $\begin{array}{l}\mathrm{N} 500,001 \\
\mathrm{~N} 1,000,000\end{array}$ & & 79 & 39.5 \\
\hline $\begin{array}{l}\mathrm{N} 1,000,001 \\
\text { above }\end{array}$ & and & 10 & 5.0 \\
\hline Total & & 200 & 100.0 \\
\hline
\end{tabular}

Source: Field Work 2018

Table 1 represents socio-economic characteristics of beneficiaries; sex distribution shows that, $70.5 \%$ of the beneficiaries were male while only 29.5 were females. This implies that, males benefits more from the community development initiatives of NGOs perhaps due to cultural norms that placed women folk as second class citizens. In northern Nigeria, women participate less in decision making and community development especially self-help efforts for reasons of long patriarchy. This is in line with Yusuf (2002) who reported that women in northern Nigeria are constrained to engage in crop production by several factors such as religious and traditional restrictions also women are exposed to time consuming domestic work or household activities. According to him, women spend long hours on collection of water from distant sources, collection of firewood, processing cooking food. Age distribution of beneficiaries shows $38.5 \%$ falls within the age range of 31-40years. While, only $2.5 \%$ were within the age range of 51-60 years. This implies that, youth participate more in community development may be due to their activeness and physical structure. Youthful age is the most critical age for human productivity in the present millennium; old age might not be able to contribute as youth can. The age bracket fallen within the age bracket defined by David et al. (2009) as economically productive in a population that is 15-65 years; also the age range is an incentive for a long lasting development. Educational qualification shows that, $49.5 \%$ of the beneficiaries had primary education while the least percentages of (7.5) and (5.5) were recorded by adult and tertiary education respectively. Education is a weapon for transformation and making people release their full potentials. This result is not a surprise considering myths and misconceptions around western education in the study area. In agreement to this finding, Aliyu (2001) documented that, low level of western education in Northern Nigeria is due to holding firmly to the ethics of Islam and having reservation against western style of education. Similarly, Edet (2004) and Cohen (1987) established that, education is a key ingredient of political, economic and social empowerment which invariably could affect engagement in rural development programmes. It has clearly show, active participation in community development efforts is dependent upon level of education of an individual or group of individuals. The more educated a community is, the more enlighten and the more they actively partake in community development in their area. Occupation distribution shows that $57 \%$ of the beneficiaries have farming as their main occupation while the least $(6.0 \%)$ were engaged in petty businesses as such handcraft, Kiosk keeping, barbing saloon, commercial motorcycles riders and water vendors. This is not unexpected because the agricultural nature of the area justified the need for emancipating the resource poor farming communities through community development activities. This is in line with Yusuf (2002) who reported that, Zamfara State is cited slightly sloppy topography with good soil suitable for agricultural production. This makes the area to have a slogan "Farming is our Pride" this finding proves that, communities participating in agricultural activities like, land clearing, irrigation and processing in the study area are practically possible. The marital status indicates $85 \%$ of the beneficiaries are married while only 15 are either single, divorced or widows. This means that marriage is not a barrier to participation in community development activities. The married are more matured and responsive to development issues. This is in agreement with findings of Sani, (2008) who argued that; marriage is highly cherished high in the rural communities of the study area. The beneficiaries' family sizes shows that, $49.5 \%$ of the beneficiaries have family size of less than 5 while the least $(1.0 \%)$ have a family size of 20 and above. This implies that, majority of the beneficiaries have less or equals to a maximum of 5 family members; they have lesser burden that might hinder their participation in community development activities. However, the family size could have effect on the income level of the beneficiaries as some of the members could contribute to the economic status of the entire family. This is contrary to findings of Manga (2012) who reported that, the average household size was 10 people per household. According to her, this large house hold size is a common characteristic of rural household especially in Northern Nigeria where polygamy is mostly practiced. The income level reveals that, $55.5 \%$ of the beneficiaries have an income of N100, $000-$ N500, 000 per annum while the least $5 \%$ have an income level of N1, 000,000 and above per annum. This is not a 
surprise because better economic status can enhance participation in community development activities through increased financial contributions towards execution of community development activities. This could also be related to kinds of occupations of the beneficiaries. If an individual is gainfully employed, he or she stands better chance of generating more incomes than unemployed. The tendency to make cash contributions for community development efforts is much higher in the former than the later.

The study revealed a positive correction (0.631) between family income and occupation. Meaning, there is significant relation between occupations and family income levels of beneficiaries. Beneficiaries with low incomes were found to be farmers and low grade civil servants. Traders and business persons reported to have higher income levels, may be due to high profits being generated from their business. To further buttress the point that, income is related to occupation of an individual and in turn can affect participation to community development activities.

Table 2: Distribution of roles of NGOs in community development as identified by NGOs

\begin{tabular}{ccc}
\hline Roles of NGOs & Frequency & Percentage \\
\hline $\begin{array}{c}\text { Promoting community self-help } \\
\text { efforts }\end{array}$ & 20 & 34.5 \\
$\begin{array}{c}\text { Training and re-training of } \\
\text { beneficiaries }\end{array}$ & 44 & 75.9 \\
$\begin{array}{c}\text { Promoting active Participation } \\
\text { Provision of Welfare Package }\end{array}$ & 28 & 48.3 \\
$\quad$ Awareness Creation and & 17 & 29.3 \\
$\quad$ Sensitization & 33 & 56.1 \\
Enhance Income Generation & 14 & 24.1 \\
$\quad$ activity & 23 & 39.7 \\
$\begin{array}{l}\text { Improving Social Services } \\
\text { Mentoring Community Based } \\
\text { Organizations }\end{array}$ & 16 & 27.6 \\
Representation of citizens at \\
decision making
\end{tabular}

Source: Field Work 2018

Table 2 shows that, $75.9 \%$ of the NGOs had attributed immense roles they played through training and re-training of community members to appreciate the value of self-help efforts. This was vigorously pursued through enlightenment and sensitization for self - awakening. This is in line with Anyanwu, (1990) that, Citizens' participation could best be achieved through training and re-training on the values of self-help which is of the people, by the people and for the people. Also Aliyu, (2012) reported that, training and capacity building is aimed at strengthening the effectiveness of an individual, which in turn enhances the level of participation in any community development programme. The finding is similar to that of Aliyu, (2012) quoting Oshuntogun (1996) who found that training strengthens people and makes them to be very efficient in discharge of their activities. Only $24.1 \%$ played role of promoting income generation activities perhaps due to their nature, most of the Local NGOs are not for profit. This implies that, community members might not be economically independent of local NGOs near future.

Table 3: Distribution of beneficiaries based on their perceptions of the contribution of NGOs in community development.

\begin{tabular}{|c|c|c|}
\hline $\begin{array}{l}\text { Contribution/effects } \\
\text { NGOs activities }\end{array}$ & Frequency & Percentage \\
\hline $\begin{array}{l}\text { Increased enrolment of } \\
\text { children in schools }\end{array}$ & 154 & 77 \\
\hline $\begin{array}{l}\text { Enhanced health care service } \\
\text { delivery }\end{array}$ & 141 & 70.5 \\
\hline $\begin{array}{l}\text { Increased yield and } \\
\text { production levels }\end{array}$ & 133 & 66.5 \\
\hline $\begin{array}{l}\text { Increased women } \\
\text { participation in development }\end{array}$ & 97 & 48.5 \\
\hline $\begin{array}{l}\text { Increased income levels of } \\
\text { community }\end{array}$ & 77 & 38.5 \\
\hline $\begin{array}{l}\text { Increased supply of basic } \\
\text { social services }\end{array}$ & 65 & 32.5 \\
\hline $\begin{array}{l}\text { Improved shelter and clean } \\
\text { environment }\end{array}$ & 48 & 24 \\
\hline $\begin{array}{l}\text { Supported eradication of } \\
\text { extreme poverty }\end{array}$ & 39 & 19.5 \\
\hline $\begin{array}{l}\text { Increased access to } \\
\text { information and knowledge }\end{array}$ & 30 & 15 \\
\hline $\begin{array}{l}\text { Reduced maternal and child } \\
\text { mortality rates }\end{array}$ & 12 & 6 \\
\hline
\end{tabular}

\section{Source: Field Work 2018}

Table 3 shows a number of effects of community development activities executed in the area by the NGOs. Increased enrolment of children in schools through mobilization and enlightenment took the lead. Where people are educated their capacities would be developed and could facilitate sense of belonging and ownership of community 
development activities and partake in community development programme. This is in line with Samuel (2005) who reported that, education being a weapon for human transformation had resulted into meaningful achievements of the yearnings and aspiration of the community through organized effort that enable the beneficiaries to realize and exploit their potentialities to the fullest. The least score recorded for reduction of maternal and child mortality is not unconnected with the fact that, majority of local NGOs don't have interest on maternal and child health related issues; the international development organizations takes lead of promoting maternal and child health related issues in the state.

Table 4: Comparism of roles played by NGOs and beneficiaries perception about NGOs contributions in community development.

\begin{tabular}{lcclclccc}
\hline Parameters & N & Mean & $\begin{array}{l}\text { Std. } \\
\text { Deviation }\end{array}$ & Df & $\begin{array}{l}\text { Level of } \\
\text { Significance }\end{array}$ & tCalculated & tCritical & Remarks \\
\hline $\begin{array}{l}\text { Roles played by } \\
\begin{array}{l}\text { NGOs in community } \\
\text { development }\end{array}\end{array}$ & 11.122 & 4.4480 & & & & & \\
& & & 17 & 0.05 & 0.446 & 1.740 & $\begin{array}{l}\text { Not } \\
\text { significant }\end{array}$
\end{tabular}

$\begin{array}{llll}\text { Beneficiaries } & 10 & 10.000 & 6.2498\end{array}$

perception towards

contributions of

NGOs

Source: Field work, 2018

$\mathrm{p}<0.05$

Table 4 shows that, $t_{\text {Calculated }}$ and $t_{\text {Critical }}$ values are 0.446 and 1.740 respectively at 0.05 level of significance. Since $t_{\text {Calculated }}$ $=0.446<\mathrm{t}_{\text {Critical }}=1.740$, this shows that, there is no significant difference in roles and perception of the contributions of NGOs in community development in the study area. Therefore, both NGOs and beneficiaries indicated same roles and contributions of NGOs to community development. This implies that, community members recognize the roles played by the local NGOs in promoting community development in their areas and that, the local NGOs claims have been verified.

Table 5: Distribution of beneficiaries based on their rules in community development

\begin{tabular}{|c|c|c|}
\hline Types of roles & Frequency & Percentage \\
\hline $\begin{array}{l}\text { Provision of communal } \\
\text { labour }\end{array}$ & 188 & 94 \\
\hline Provision of water & 149 & 74.5 \\
\hline $\begin{array}{l}\text { Provision of venue for } \\
\text { training activities }\end{array}$ & 125 & 62.5 \\
\hline Provision of transportation & 97 & 48.5 \\
\hline Making cash donations & 60 & 30 \\
\hline Active participation include & 37 & 18.5 \\
\hline
\end{tabular}

planning

Others

22

11

\section{Source: Field Work 2018}

Table 5 shows that, beneficiaries have participated actively in various community development activities through provision of labour and other forms of assistance that are essential in the realization of community development Objectives. This is not a surprise because community members are the greatest resources for their own betterment. This is contrary to the findings of Samuel (2005) that reported monetary contribution and family labour were the main modes of community participation by both male and female (40.3\% and $37.5 \%$ ) respectively. According to him, majority of female group (47.9) quoting Akinsorotan and Olujide (2003) who assessed the level of participation of community development association members in self-help project in Lagos State where $52 \%$ of the respondents contributed money, time and labour, $14 \%$ participated by providing money, only $4 \%$ and $26 \%$ served as implementation committee members. 
Table 6: Perception of beneficiaries on NGOs efforts towards community development $(n=200)$

\begin{tabular}{lll}
\hline Parameters & Frequency & Percentage \\
\hline Improvement $\quad$ of & living & \\
standards & & \\
SA & 108 & 54.0 \\
A & 66 & 33.0 \\
N & 14 & 7.0 \\
D & 9 & 4.5 \\
SD & 3 & 1.5 \\
Promotion of self-help Efforts & & \\
SA & 59 & 29.5 \\
A & 89 & 44.5 \\
N & 34 & 17.0 \\
D & 12 & 6.0 \\
SD & 6 & 3.0 \\
Improve Welfare & & \\
SA & 81 & 40.5 \\
A & 66 & 33.0 \\
N & 29 & 14.5 \\
D & 11 & 5.5 \\
SD & 13 & 6.5 \\
Extent of contribution & & \\
Great & 75 & 37.5 \\
Moderate & 88 & 44.0 \\
Low & 30 & 15.0 \\
None of All & 7 & 3.5 \\
Total & $\mathbf{2 0 0}$ & $\mathbf{1 0 0 . 0}$ \\
\hline Sourc: Field Work 2018 & &
\end{tabular}

Source: Field Work 2018

Key: $S A=$ Strongly Agreed; $A=$ Agreed $;=$ Neutral $; D=$ Disagreed; $S D=$ Strongly Disagreed

Table 6 shows that, the NGOs had contributed immensely towards improvement of lives and expectancy and had resulted in the improvement of community welfare and productivity. This is likely so because people always appreciates who benefit them. The indifferent could be attributed to low level of education of the beneficiaries that could not critically analyze previous and current situations to be able to tell if there is any change. In agreement to this finding is the result of Manga (2012) who reported that support is sometimes extended to individuals, group and communities and is aimed at improving their livelihood activities and is expected to result in their improved wellbeing.
Table 6 shows that, beneficiaries had attested to the fact that, NGOs promotes self-help efforts in the community. This is not surprising as government and non-governmental interventions are not permanent in the communities and hence, the need for the community member to help themselves. This is in line with Zaki (2003) 'rural communities are faced with numerous problems and government alone cannot provide everything for all its citizens, hence community groups are formed to arrest such problems. This was further corroborated with principles of community development by Anyanwu (1999) who reported that principle of self-help - this is the main end product of community development. Enables people to exploit to their advantages the resources which could otherwise be dormant. Make use of under-utilized labour. Increase the component and confidence of a community in the heading of its affairs. Constitute a pre-requisite for survival in the modern world. Enables people to change the way they look at their responsibilities, and help them to cultivate the sense of local initiative and effort. Enhances the development of democratic values and processes; promote the idea of ultimate control by the people; fosters a substantial degree of freedom by individual and groups; leads to a considerable amount of government decentralization. Promotes wide spread citizens participation.

Table 6 shows, that beneficiaries have confessed that, NGOs activities in the study area are enormous to changing welfare status of beneficiaries through series of welfare packages and income generation activities that improves economic capabilities of beneficiaries. If people sufferings are eliminated they tend to be removed from bondage of poverty and insecurity. Their lives will be better up. This result is similar that of Adeola, et al. (2008) that conducted a research on the effect of the federal government special programme on rice yield and farmers' income and reported an increase in mean income of the respondents after the programme and concluded that the programme has impacted positively on the respondents.

Table 6 shows that NGOs efforts in improving community are of great importance to the beneficiaries and had acknowledged NGOs roles. These efforts were well received and appreciated by the beneficiaries. The least score 3.5\% that reported none at all might be due to lack of awareness that a particular effort is done by an NGO not government. 
Table 7: Comparison of the perception of the roles of NGOs by the beneficiaries according to Sex.

\begin{tabular}{lllllllll}
\hline Sex & N & Mean & $\begin{array}{l}\text { Std. } \\
\text { Deviation }\end{array}$ & Df & $\begin{array}{l}\text { Level of } \\
\text { Significance }\end{array}$ & tCalculated & tCritical & Remarks \\
\hline Male & 141 & 7.50 & 2.609 & 198 & 0.05 & 0.695 & 1.645 & Not significant \\
& & & & & & & & \\
Female & 59 & 7.81 & 3.442 & & & & & \\
\hline
\end{tabular}

Source: Field work, 2018

Table 7 revealed that, $\mathrm{t}_{\text {Calculated }}$ andt ${ }_{\text {Critical }}$ values are 0.695 and 1.645 respectively at 0.05 level of significance. Since $t_{\text {Calculated }}$ $=0.695<\mathrm{t}_{\text {Critical }}=1.645$. This indicates that, there is no significant difference in perceptions of the roles of NGOs by beneficiaries based on sex. Hence, both males and females in this study perceived the roles of NGOs as the same. Even though women were not many in the study but the result shows same perceptions perhaps men had influenced their choice. Women are always submissive to the will of their husband, hence the influence.

Table 8: Distribution of beneficiaries' perception of problem of $N G O s$

\begin{tabular}{lll}
\hline $\begin{array}{l}\text { Problems of community } \\
\text { Development }\end{array}$ & Frequency & Percentage \\
\hline $\begin{array}{l}\text { Financial constraints } \\
\begin{array}{l}\text { Inadequate personnel to } \\
\text { implement program }\end{array}\end{array}$ & 164 & 94.5 \\
$\begin{array}{l}\text { Low level of community } \\
\text { commitments }\end{array}$ & 120 & 60 \\
$\begin{array}{l}\text { Low level of government } \\
\text { support to NGOs }\end{array}$ & 61.5 \\
$\begin{array}{l}\text { Negative attitudes of } \\
\text { beneficiaries } \\
\text { community development }\end{array}$ & 10 \\
\hline
\end{tabular}

Source: Field Work 2018

*Multiple response

Table 8 shows that NGOs face a number of problems that hinder their development. Inadequate funds and funding support constitutes a great challenge towards achieving their desired objectives. While the least was the poor attitudes of beneficiaries to community development. This is in line with Keck and Kathryn, (1998)" Funds play a vital role in any NGO for execution of its projects, Programmes or activities, which are development oriented to their community. Hence funding agencies, donors, sponsors, are very important to all NGOs".

Table 9: Distribution of problems of NGOs as perceived by themselves (NGOs)

\begin{tabular}{lll}
\hline Problems of NGOs & Frequency & Percentage \\
\hline Financial constraints & 50 & 86.2 \\
$\begin{array}{l}\text { Inadequate personnel/staff } \\
\text { Low level of community }\end{array}$ & 24 & 41.4 \\
$\begin{array}{l}\text { commitments } \\
\text { Low level of government }\end{array}$ & 29 & 36.2 \\
$\begin{array}{l}\text { and donor support } \\
\begin{array}{l}\text { Negative attitude of } \\
\text { beneficiaries to community } \\
\text { development }\end{array}\end{array}$ & 50 \\
\hline
\end{tabular}

Source: Field Work 2018 *Multiple response

Table 9 shows that, NGOs have realized that they face some problems that affect their full performance and financial constraint took the lead. The least $10.1 \%$ was the poor attitudes of beneficiaries towards community development activities. This implies that, inadequate funds and funding support constitutes a great challenge towards achieving the desired objectives. This means that, achieving significant impacts of promoting community development initiatives in the study area might not be realized if funds are not available.

Table 10: Comparison of proportion of NGOs problems by beneficiaries and NGOS

\begin{tabular}{|c|c|c|c|c|c|c|c|}
\hline Person square & Chi- & $\begin{array}{l}\text { Number of } \\
\text { valid cases }\end{array}$ & Df & $\begin{array}{l}\text { Level of } \\
\text { Significance }\end{array}$ & $\mathbf{x}^{2}$ Calculated & $\mathrm{x}^{2}$ Critical & Remarks \\
\hline $\begin{array}{l}\text { Beneficiaries } \\
\text { and NGOs }\end{array}$ & & 200 & 4 & 0.05 & 7.134 & 9.49 & $\begin{array}{l}\text { Not } \\
\text { significant }\end{array}$ \\
\hline
\end{tabular}

Source: Field work, 2018 
Table 10 shows that $x^{2}$ Calculated and $x^{2}$ Critical values are 7.134 respectively at 0.05 level of significance. Since $\mathrm{x}^{2}$ Calculated $=$ $7.134<x^{2}$ Critical $=9.49$. This indicates that, there is no significant difference in the proportion of problems of NGOs as perceived by the beneficiaries and the NGOs themselves. Hence, both have same perceptions in regards to Problems that hinder NGOs progress towards community development programs. This implies that, NGOs and beneficiaries can jointly work together to address the impediments identified and that, the problems identified is no longer that of NGOs alone but the communities themselves.

Table 11: Distribution of beneficiaries according to forms of assistance required from government to supplement the efforts of the NGOs

\begin{tabular}{|c|c|c|}
\hline Forms of assistance & Frequency & Percentage \\
\hline Increase funding support & 149 & 74.5 \\
\hline $\begin{array}{l}\text { Increase level playing } \\
\text { ground }\end{array}$ & 126 & 63 \\
\hline $\begin{array}{l}\text { Collaboration } \quad \text { and } \\
\text { engagement }\end{array}$ & 130 & 65 \\
\hline $\begin{array}{ll}\text { Support } & \text { program } \\
\text { implementation } & \end{array}$ & 130 & 65 \\
\hline Administrative support & 87 & 43.5 \\
\hline $\begin{array}{l}\text { Capacity development } \\
\text { opportunities }\end{array}$ & 35 & 17.5 \\
\hline $\begin{array}{l}\text { Enabling environment for } \\
\text { donors }\end{array}$ & 33 & 16.5 \\
\hline
\end{tabular}

Source: Field Work 2018 *Multiple response

Table 11 shows that, for NGOs to be effective in their functions, there is need for government and other institutions to provide assistance such as funds and skills to the NGOs. In line with Samuel (2005) who reported that, government provides funds, contracts and training opportunities to give special encouragement to NGOs activities in priority areas without undermining NGOs autonomy and independence; broad agreement is sought with NGOs on such priorities by establishing formal consultation with NGO leaders. For a such as the Council for Advancement of People Action and Rural Technology (the body which channels government funds to NGOs in India) and the forthcoming Community Action Program (a local government scheme for financing NGOs and community initiatives in Uganda) are illustrations.

\section{CONCLUSION}

From the findings of the study, it could be concluded that NGOs has immensely contributed to community development initiatives through training and re-training as well as sensitization and mobilization of beneficiaries on the importance of self-help. It could be concluded that beneficiaries also contributes to their development if adequately mobilize to do so. It was further more concluded that, beneficiaries have positive perception to the critical roles of NGOs towards improving their livelihoods. It could be also concluded that, occupation of beneficiaries determines their income level and that is no significant difference in the perceptions of beneficiaries on the roles and problems of NGOs in the study area.

\section{RECOMMENDATIONS}

After careful examining the roles of local NGOs in community development in the study area and results that depicts challenges to community development in the area; the following recommendations were proposed to make NGOs effective in delivering community development services.

1. Government, individuals and other agencies should increase their support to NGOs. these support should include, provision of enabling working environment, provision financial, materials and technical report.

2. Beneficiaries of community development programmes and activities should continue to support activities of the NGOs in their areas and should ensure maintenance and sustainability of the completed community development projects.

3. Citizens should form and more local NGOs to complement government efforts towards community development.

4. NGOs should be more dedicated in execution of community development activities especially through promotion of self-help. They should also be interested in promoting livelihoods of rural dwellers;

5. NGOs should always carry beneficiaries along planning, execution and even evaluation of any community development activities in their domain. This will promote sustainability and ownership of the project.

6. Beneficiaries should increase their participation levels in community development through actively contributing to all community development efforts. 
Maintenance culture of beneficiaries for project executed by the NGOs should be sustain;

\section{REFERENCES}

[1] Adeola, R.G, O.O Adebayo and G.O Oyelere (2008), Effects of Federal Government Special Rice Programme on Rice Yield and Farmers income in Oyo state. International Journal of Agricultural Economics and Rural Development. Vol. 1 No. 1 pp 124.

[2] Aliyu, B (2002), Introduction to Sociology Studies. $1^{\text {st }}$ ed. Kano; Zonnet Press. Pp 47

[3] Anyanwu, C.N. (1999), Introduction to Community Development. Gabesther Education Publishers Ibadan, Pg 143.

[4] Cohen, J.M (187). Rural Development participation. Concepts and measure for project design implementation and evaluation. $3^{\text {rd }}$ ed. New York: itace Publishers, Pp 123

[5] David, H.D.S, Abdulrahman, R.M, Sani, S. Kushawa and M Nasiru (2009), Resource use efficiency in irrigated Crop Production by Fadama users in Bauchi State, Nigeria; implication for Food Security and Poverty alleviation. Proceedings of the $23^{\text {rd }}$ annual conference of Farm management of Nigeria, Faculty of Agriculture, Usmanu Danfodiyo University, Sokoto, Nigeria, $14^{\text {th }}-17^{\text {th }}$ December, 2009, Pp 111.

[6] Edet, C (2004). Impact of rural development on infrastructural development. A case study of Zaria LGA An unpublished thesis, ABU Zaria Pp. 187

[7] Keck, M.E and S Kathryn (1998), Non-governmental organizations and their efforts. Oxford University Press; pp 284

[8] Manga, A.T (2012), Role of International Fund for Agricultural Development/Community based Agriculture and Rural Development in Poverty Reduction among women in Kebbi state, Nigeria. Unpublished MSc. Thesis Department of Agricultural Extension and Rural Development, Usmanu Danfodiyo University Sokoto, Nigeria

[9] National Population Commission NPC) 2006 census data. www.npc.gov.ng

[10] Samuel, U.T (2005), the Role of Non-governmental Organizations (NGOs) in Development. A paper prepared for Coalition of NGOs in Delta State. Nigeria Village square Publishers.

[11] Sani, M.K (2008). Impact of Community based Agricultural and Rural Development Programme on Livelihoods of selected LGAs of Sokoto State, Nigeria, Unpublished Msc thesis. Department of Agricultural Economics and Extension, Usmanu Danfodiyo University Sokoto, Nigeria.

[12] United Nations (1990), Community New York, Oxford University Press.

[13] Yusuf, A. (2002), Roles of Government in Financing NGOs. The Central Bank of Nigeria Journal of Economics 39(5); Pp 162
[14] Zaki, B.A (2003), Rural Community development. Lecture manuscripts, Usmanu Danfodiyo University, Sokoto; Unpublished document.

[15] Zamfara State Government Bulletin, 2012 First edition, State Government Press. Pp. 45. 